ISSN 1392-3196 / e-ISSN 2335-8947

Zemdirbyste-Agriculture, vol. 105, No. 2 (2018), p. 177-182

DOI 10.13080/z-a.2018.105.023

\title{
Cacopsylla pruni in Poland and its significance as a vector of 'Candidatus Phytoplasma prunorum'
}

\author{
Wojciech WARABIEDA, Grażyna SOIKA, Mirosława CIEŚLIŃSKA \\ Research Institute of Horticulture in Skierniewice \\ Konstytucji 3 Maja 1/3, 96-100 Skierniewice, Poland \\ E-mail: wojciech.warabieda@inhort.pl
}

\begin{abstract}
The species composition of jumping plant-lice, especially Cacopsylla pruni as a vector of 'Candidatus Phytoplasma prunorum', was researched on stone fruit trees in 53 locations, mainly in Central Poland. Twelve species were found to belong to the families Psyllidae, Aphalaridae and Triozidae. C. pruni which made up 59.9\% of the collected specimens was noted in eight locations in plum orchards and in two locations in cherry orchards. Only three locations were found to have specimens of $C$. pruni which were infected by ' $C a$. $\mathrm{Ph}$. prunorum', namely on plum trees in the Lesser Poland Province and plum and mirabelle plum trees in the Masoovian Province. In the latter location, specimens of $C$. pruni infected with ' $C a$. Phytoplasma asteris' were also caught in mirabelle plum trees. We can conclude that at this moment $C$. pruni is not a significant threat to Polish stone fruit orchards and its importance in the possible spread of phytoplasma causing European stone fruit yellows is low.
\end{abstract}

Key words: ‘Candidatus Phytoplasma asteris', European stone fruit yellows.

\section{Introduction}

Cacopsylla pruni (Scopoli) is widely distributed in Europe on oligophagous, univoltine species on plants belonging to the genus Prunus (Steffek et al., 2012). This species has been found in many locations in Poland: Pomeranian Lakeland, Masurian Lakeland and Małopolska Upland (Klimaszewski, 1963), KrakówCzęstochowa Upland (Smreczyński, 1954), in the Western Beskids, Nowy Targ Basin, in many places in Pieniny and the Tatra Mountains (Smreczyński, 1954; Drohojowska, Głowacka, 2011) and in the Silesian Upland (Kanturski, Drohojowska, 2013).

According to Klimaszewski (1967), in Poland, C. pruni commonly occurred on plants of the genus Prunus, but due to the relatively small population, this species did not cause economic losses. However, it has been proved that $C$. pruni is a vector of the 'Candidatus Phytoplasma prunorum' ('Ca. Ph. prunorum') (Carraro et al., 1998). The presence of this quarantine pathogen, which causes many diseases on Prunus trees described as European stone fruit yellows (ESFY), has been reported from most of the countries in the European Union (Steffek et al., 2012). This disease was first described on Japanese plum (Prunus salicina Lindley) in Italy (Goidanich, 1933 ) and has now become a serious problem affecting European producers of apricots (Prunus armeniaca L.), Japanese plums and peaches ( $P$. persica L.). The highest occurrence of ' $\mathrm{Ca}$. Ph. prunorum' has been found in the countries of the Mediterranean Basin (Thébaud et al.,
2009; Cieślińska, Morgaś, 2011; Steffek et al., 2012; Sabaté et al., 2015).

The study recently carried out in Polish orchards has pointed to the presence of this pathogen in plum and peach as well as sweet and sour cherry crops (Cieślińska, Morgaś, 2011; Cieślińska, Smolarek, 2015). However, the scale of damage caused by ' $\mathrm{Ca}$. Ph. prunorum' in Poland is not sufficiently well-known. So far, studies on the occurrence and identification of potential vectors of this phytoplasma in Poland have not been carried out.

The aim of this research was to determine the composition of Psylloidea with particular emphasis on Cacopsylla pruni on Prunus plants in orchards as well as those growing in the natural environment in selected regions of Poland and to determine the incidence of specimens testing positive for 'Candidatus Phytoplasma prunorum' in order to assess the risk of this phytoplasma spreading.

\section{Material and methods}

The species composition of Psylloidea on plants of the genus Prunus. A study on the occurrence of psyllids was carried out between 2013 and 2016 inclusive in 53 locations in different regions of Poland, mainly in the central area. Besides plum, the monitoring included peach and apricot as well as sweet and sour cherry trees. Additionally, samples were also taken from plants

Please use the following format when citing the article:

Warabieda W., Soika G., Cieślińska M. 2018. Cacopsylla pruni in Poland and its significance as a vector of 'Candidatus Phytoplasma prunorum' . Zemdirbyste-Agriculture, 105 (2): 177-182 DOI 10.13080/z-a.2018.105.023 
growing close to the surveyed orchards, mainly from blackthorn (Prunus spinosa L.), and also from coniferous trees such as Pinus spp. and Picea spp. which are known to be the overwintering places of jumping plant-lice species, including Cacopsylla pruni. Samples were taken using the beat-tray method. A sample collection unit was defined as the number of individual specimens obtained from 100 randomly selected branches from a randomly selected test area of approximately 0.5 hectares at each test location.

The collected insect specimens were checked under a stereoscopic microscope and identified to individual species using the entomological key (Ossiannilisson, 1992). The classifications follow that of Burckhardt and Ouvrard (2012). Specimens of C. pruni were preserved in $70 \%$ ethanol at $-20^{\circ} \mathrm{C}$ until testing for the presence of phytoplasma.

Identification of the phytoplasma in Cacopsylla pruni. The total DNA was extracted from samples of $C$. pruni consisting of 1-3 individuals using a High Pure PCR Template Preparation Kit (Roche). The DNA was subjected to nested polymerase chain reaction (PCR) assay with the universal primer pair P1/P7 (Deng, Hiruki, 1991; Schneider et al., 1995) for amplification of $1.8 \mathrm{kbp}$ product of the $16 \mathrm{~S}$ ribosomal DNA, the spacer region between the $16 \mathrm{~S}$ and $23 \mathrm{~S}$ rDNA genes and the 5'-end of the 23S rDNA of the phytoplasmas. P1/P7 amplicons, diluted 1:29 with sterile water, were used as templates for the second round of PCR with the universal primer pair R16F2n/R16R2 (Gundersen, Lee, 1996). All PCR assays were performed with a thermocycler PTC-200 (MJ Research, USA), and $7 \mu$ of the amplification products was separated in $1 \%$ agarose gel in $0.5 \times \mathrm{TBE}$ (tris-borateEDTA) buffer, followed by staining in ethidium bromide and visualization of DNA bands using UV transilluminator (Syngen, England). The molecular weight of the PCR products was estimated by comparison with $100 \mathrm{bp}$ DNA ladder (Thermo Scientific Ltd., Lithuania). Five $\mu$ l of the nested PCR products were separately digested with $R s a \mathrm{I}$ and SspI restriction endonucleases (Thermo Scientific Ltd.). The generated restriction patterns were analysed by electrophoresis in $8 \%$ polyacrylamide gels in $1 \%$ TBE buffer and compared with the profiles of the following strains, collected by A. Bertaccini (http://www.ipwgnet. org/collection); 'Canadidatus Phytoplasma prunorum' (16SrX-B), 'Ca. Ph. mali' (16SrX-A), ' $\mathrm{Ca}$. Ph. pyri' $(16 \mathrm{SrX}-\mathrm{C})$ and ' $\mathrm{Ca}$. Ph. asteris' (16SrI-B). These strains were also compared with previously published restriction fragment length polymorphism (RFLP) patterns of phytoplasmas (Lee et al., 1998).

\section{Results and discussion}

The species composition of jumping plantlice. During the study, a total of 178 samples of insects were taken from 53 locations, both from stone fruit trees growing in orchards and plants from surrounding area (Fig. 1).

Twelve jumping plant-lice species were identified in the collected samples, which were classified as belonging to three families: Psyllidae, Aphalaridae and Triozidae. The most represented family was Psyllidae with eight species of psyllids while Aphalaridae and Triozidae were represented only by a small number of species (Table 1).

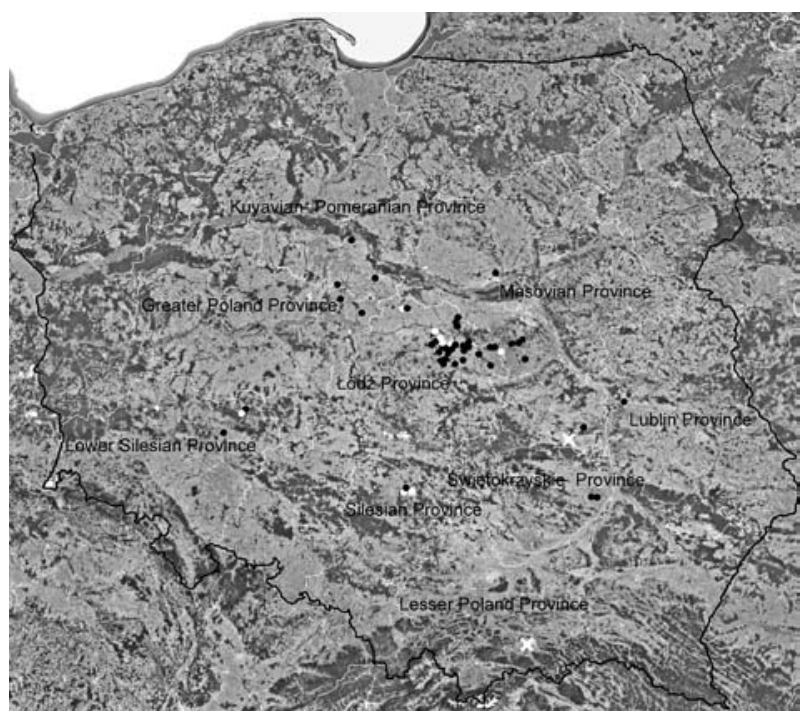

○-C. pruni found, $\bullet-C$. pruni not found, $\mathrm{X}-{ }^{\text {'Candidatus }}$ Phytoplasma prunorum' found in Cacopsylla pruni bodies

Figure 1. Locations surveyed in order to determine the presence of jumping plant-lice

The percentage of $C$. pruni caught on trees or shrubs differed depending on the plant species, making up $66.9 \%$ of all specimens collected from plums (Fig. $2 \mathrm{~A}$ ), $6.4 \%$ of specimens from sweet and sour cherries (Fig. 2 B), $35.0 \%$ of specimens on blackthorn (Fig. 2 C) but only $1.5 \%$ of the specimens collected from coniferous trees (Fig. 2 D). This may suggest that plum trees are among the preferred host plants of $C$. pruni. The $C$. pruni occurrence was observed in plum orchards primarily in the spring (March-May), but not in the summer (June-July). Similar results were obtained in the studies conducted in other countries, e.g., in France and Spain (Labonne, Lichou, 2004; Thébaud et al., 2009; Sabaté et al., 2015).

Among the psyllids collected from Prunus plants, a high proportion of $C$. melanoneura was noted. It should be pointed out that in contrast to males, the females of $C$. melanoneura and $C$. affinis are impossible to distinguish by morphological criteria (Tedeschi et al., 2009). However, given that only two C. affinis specimens were found of the dozens of males belonging to these two species, it can be said that $C$. melanoneura was the dominant species in this complex.

Relatively large number of individuals of this species caught is probably related to the fact that in the spring this species re-migrates from its overwintering sites to hawthorn or apple trees being the most commonly cultivated fruit tree in Poland. Plum trees, as well as other fruit plants, could potentially be only "accidental" feeding or landing places for C. melanoneura at this time of year.

It has been shown that among plants in the surrounding orchards, $C$. pruni was found much more often in blackthorn than in coniferous plants in the growing season (Table 2, Fig. $2 \mathrm{C}$ and D). The fact that the $C$. pruni prefers blackthorn has been confirmed and described by other researchers (Labonne, Lichou, 2004). On the other hand, this psyllid readily overwinters on conifer plants, located at some distance from stone fruit tree orchards (Yvon et al., 2004; Čermak, Lauterer, 2008). In our study, however, samples were largely taken from 
Table 1. A list of Psylloidea species collected in 2013-2016

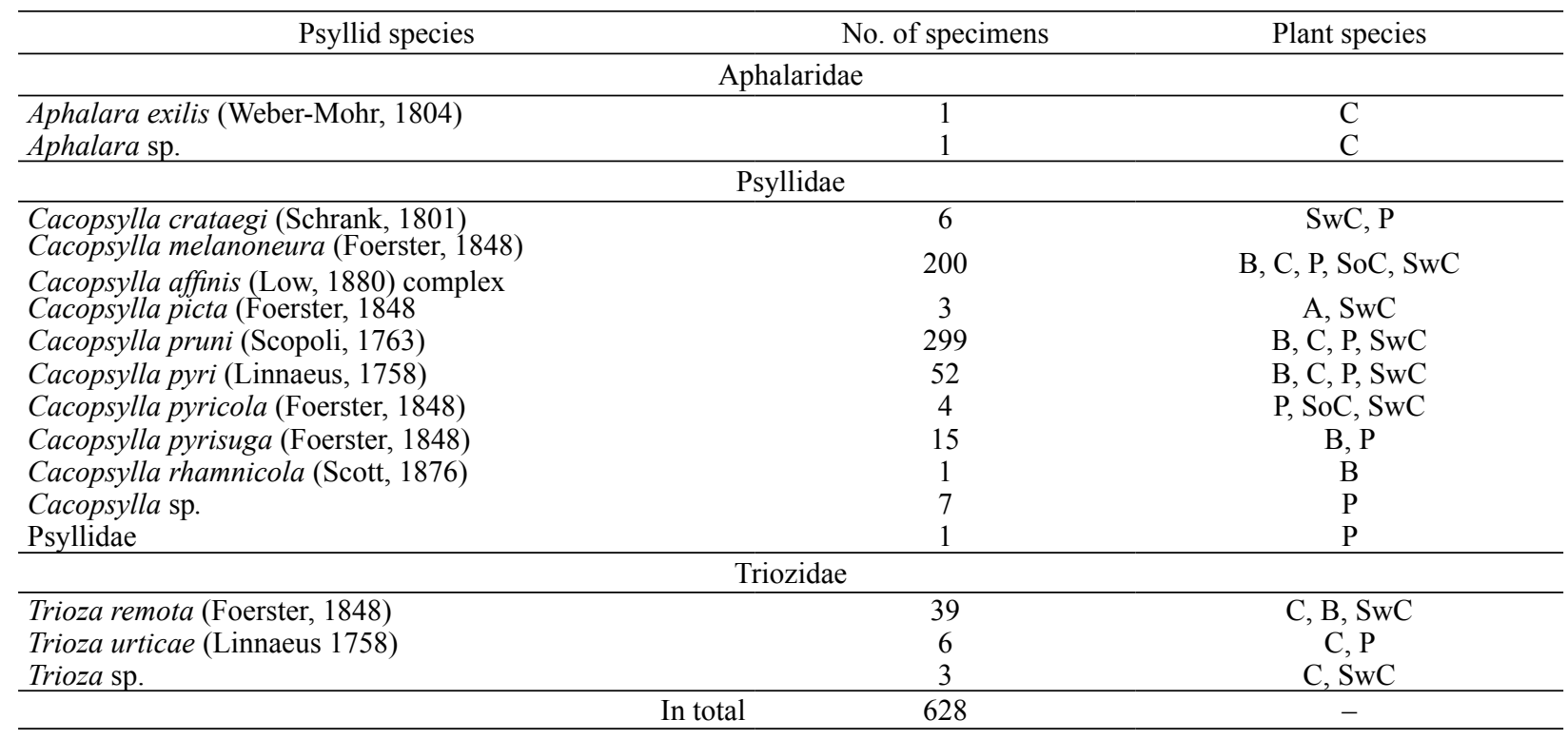

A - apricot, B - blackthorn, C - conifers, P - European plum, SoC - sour cherry, SwC - sweet cherry
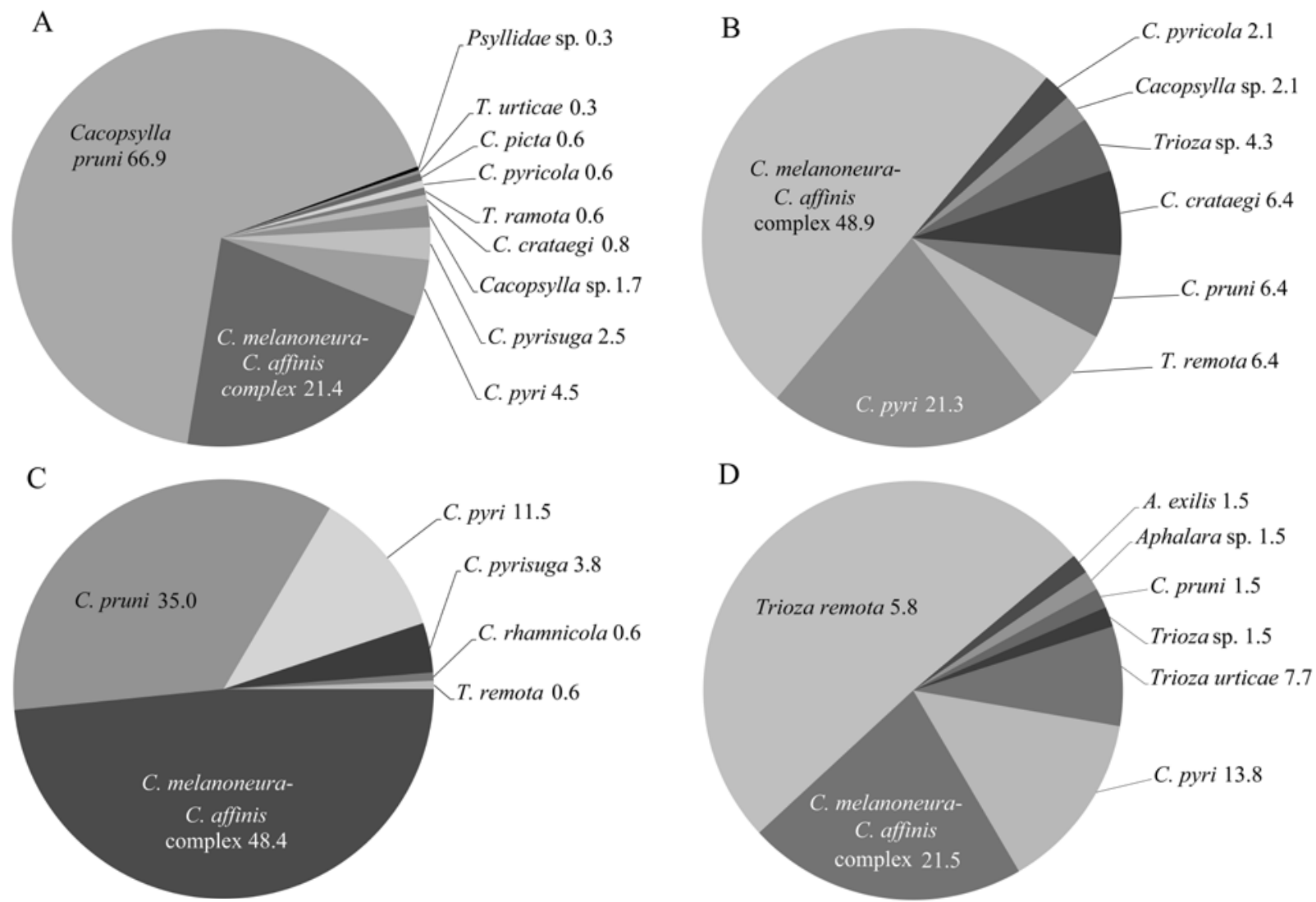

Figure 2. Percentages of jumping plant-lice collected from plum trees (A), sweet and sour cherry (B), blackthorn (C) and conifers (D)

conifers growing in the immediate vicinity of the surveyed orchard, which could be the reason why a relatively small number of $C$. pruni were collected. Although $C$. pruni was the most numerous species on Prunus, considering its frequency of occurrence in the samples, as well as its occurrence in various locations, it can be concluded that this species usually occurs sporadically and locally. In general, the presence of $C$. pruni was noted in 26 samples, coming from 11 locations (Fig. 1, Table 2).
It should be noted that during this study, observations were carried out mainly in protected orchards, in which the number of psyllids could have been reduced as a result of chemical treatments carried out against other pests. Such a possibility is indicated by the results obtained in one of the villages in Masovian Province in 2016. In this area, C. pruni was not recorded in the tested plum orchard, which was surrounded by apple trees chemically protected against $C$. melanoneura. However, 
Table 2. The frequency of Cacopsylla pruni occurrence

\begin{tabular}{lcc}
\hline \multicolumn{1}{c}{ Plant species } & $\begin{array}{c}\text { No of samples with } \text { C. pruni / } \\
\text { the total number of samples }\end{array}$ & $\begin{array}{c}\text { No of locations with C. pruni / } \\
\text { the total number of locations }\end{array}$ \\
\hline Plum & $16 / 85(18.8 \%)$ & $8 / 31(25.8 \%)$ \\
Peach and apricot & $0 / 6$ & $0 / 5$ \\
Sweet and sour cherry & $2 / 56(3.6 \%)$ & $2 / 33(6.1 \%)$ \\
Blackthorn & $7 / 20(35 \%)$ & $6 / 13(46.2 \%)$ \\
Conifers & $1 / 17(5.9 \%)$ & $1 / 12(8.3 \%)$ \\
\hline
\end{tabular}

this species occurred relatively frequently on unprotected mirabelle plum trees growing at some distance from those protected apple trees. The effect of chemical treatments on C. pruni density is indirectly indicated by the fact that, on wild, unprotected blackthorn, this species occurred in $46.2 \%$ of the monitored locations and in $35.0 \%$ of the samples, while in protected plum orchards $C$. pruni was noted in only $25.8 \%$ of the monitored locations and in $18.8 \%$ of the samples (Table 2). On the other hand, the preference of blackthorn by $C$. pruni cannot be ruled out (Lauterer, 1999; Labonne, Lichou, 2004).

Occurrence of phytoplasmas. Of the 261 specimens of $C$. pruni which were analysed for phytoplasma infection, 203 were collected from plum trees, 53 from blackthorn, four from cherry, and one from conifers. The presence of ' $\mathrm{Ca}$. Ph. prunorum' in the $C$. pruni bodies was limited geographically, since the pathogen was detected in only two of the eleven localities where this psyllid species was found. ' $\mathrm{Ca}$. Ph. prunorum' was identified in three samples of psyllids that came from Masovian Province (one sample from plum trees growing in an orchard and two from the chemically unprotected mirabelle plum trees (Prunus domestica subsp. syriaca) growing nearby) and one from a plum orchard located in the Lesser Poland Province (Fig. 3).
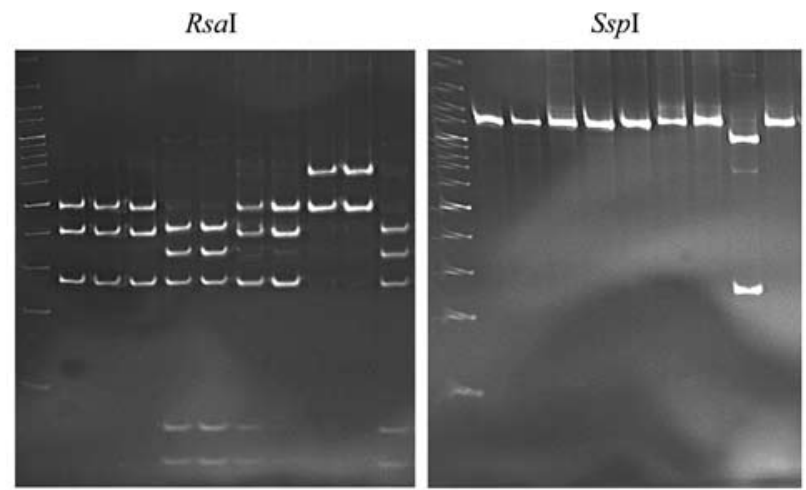

$\begin{array}{lllllllllllllllllllll}\mathrm{L} & 1 & 2 & 3 & 4 & 5 & 6 & 7 & 8 & 9 & 10 & \mathrm{~L} & 1 & 2 & 3 & 4 & 5 & 6 & 7 & 8 & 9\end{array}$

Lanes: $\mathrm{L}$ - molecular marker $100 \mathrm{bp} ; 1-$ C. pruni from plum (Masovian Province), $2-$ C. pruni from plum (Lesser Poland Province), 3-6-C. pruni from mirabelle plum tree (Masovian Province), $7-\mathrm{K}^{+}$' $C a$. Ph. prunorum', $8-\mathrm{K}^{+}$'Ca. P. mali', $9-$ $\mathrm{K}^{+}$'Ca. P. pyri', $10-\mathrm{K}^{+}$'Ca. P. asteris'

Figure 3. Polyacrylamide gel showing the restriction fragment length polymorphism (RFLP) patterns of phytoplasmas ribosomal DNA fragment amplified with R16F2n/R16R2 primers digested with RsaI and SspI restriction enzymes of Cacopsylla pruni samples from Prunus sp. trees surveyed in Masovian Province and Lesser Poland Province
Furthermore, it was found that the level of psyllid infection differed between years. For example, in one of the orchards in Lesser Poland Province the level varied between $1.6 \%$ and $4.7 \%$ (for 64 collected individuals) in 2013, while in 2014 ' $\mathrm{Ca}$. Ph. prunorum' was not detected in any of the 43 collected specimens. Similarly, in the orchard in the Masovian Province, the infection rate in 2013 for 21 tested specimens of C.pruni was between $4.8 \%$ and $14.3 \%$, while in 2016 the presence of phytoplasma was not detected in the bodies of insects.

Generally, considering analysis of the total number of $C$. pruni specimens (207) collected from stone fruit trees in all the test locations and tested for the presence of ' $\mathrm{Ca}$. Ph. prunorum', the degree of infection by this pathogen can be estimated at between $1.9 \%$ and $5.3 \%$, or, if we also include specimens collected from blackthorn (53) and coniferous plants (1), the infection rate was between $1.5 \%$ and $4.2 \%$. These values were lower than those obtained for $C$. pruni in the apricot orchards in Moravia, or in stone fruit orchards in several regions of Spain, where the rate of infection in the spring period reached tens of percent (Fialová et al., 2004; Sabaté et al., 2015).

Interestingly, two samples of $C$. pruni individuals, caught on mirabelle plum trees in Masovian Province were infected with ' $\mathrm{Ca}$. Ph. asteris'. On the same plants, $C$. pruni infected with ' $C a$. Ph. prunorum' were found, which confirms that a single psyllid species can carry more than one pathogen. On the other hand, the same phytoplasmas may be transferred between plants by various insects (Weintraub, Beanland, 2006; Bosco et al., 2007). Previous studies indicate that the aster yellows group phytoplasmas are transmitted by different species of leafhoppers. In the literature, there is no information on the transfer of these pathogens by $C$. pruni. Research in this area should be extended and include a greater number of tests to confirm or rule out the relationship between $C$. pruni and ' $C a$. Ph. asteris'.

The threat to stone fruit trees by ESFY depends on many factors. Apart from vector abundance and the level to which they are infected with phytoplasma, differences in the susceptibility of Prunus spp. plants to ' $\mathrm{Ca}$. $\mathrm{Ph}$. prunorum' are also important. Species susceptible to the phytoplasma include Japanese plum, apricot and peach, while plum, sweet cherry, sour cherry, blackthorn and cherry plum are either rarely infected or are at least tolerant to infection (Giunchedi et al., 1982; Jarausch et al., 2000; Carraro et al., 2002). The stone fruit trees grown in Polish orchards are mostly tolerant to phytoplasma. Peach and apricot trees account for only about $6.3 \%$ of stone fruit tree plantings, while Japanese plum accounts for no more than $1 \%$.

Due to the relatively large area of host plants and the presence of both the pathogen and its vector in 
Poland, under favourable conditions the threat to Polish orchards by ESFA may change. One other factor that is becoming more relevant is the observed climate change taking place in Poland (Tomczyk et al., 2015). There is evidence that climate warming is having an effect on population size increase of many pests (Krishnareddy, 2013). The increase in air temperature and drought can promote not only the development of psyllids, but also the phytoplasma multiplication in the cells of host plant and in the insect vector. In consequence, this may lead to an increased risk of ESFY occurrence in the orchards. In addition, economic losses in the future may be higher if the planting of thermophilic plants, particularly those sensitive to infection by ' $C a$. Ph. prunorum' such as apricot, peach or Japanese plum increases.

\section{Conclusion}

The study showed that at this moment Cacopsylla pruni is not a significant threat to Polish stone fruit orchards and its importance in the possible spread of phytoplasma causing European stone fruit yellows is low.

\section{Acknowledgements}

The research was supported by the Polish Ministry of Science and Higher Education as part of the statutory activities (4.2.5) of the Department of Plant Protection, Research Institute of Horticulture in Skierniewice and partially financed by National Science Centre, Poland grant No. UMO-2013/08/M/NZ9/00138, in the frame of COST FA1104.

Received 10082017

Accepted 15012018

\section{References}

1. Bosco D., Galetto L., Leoncini P., Saracco P., Raccah B., Marzachi C. 2007. Interrelationships between 'Candidatus Phytoplasma asteris' and its leafhopper vectors. Journal of Economic Entomology, 100: 1504-1511. https://doi.org/10.1603/0022-0493-100.5.1504

2. Burckhardt D., Ouvrard D. 2012. A revised classification of the jumping plant-lice (Hemiptera: Psylloidea). Zootaxa, 3509: 1-34.

https://doi.org/10.11646/zootaxa.3509.1.1

3. Carraro L., Osler R., Loi N., Ermacora P., Refatti E. 1998. Transmission of European stone fruit yellows phytoplasma by Cacopsylla pruni. Journal of Plant Pathology, 80: 233-239.

4. Carraro L., Ferrini F., Ermacora P., Loi N. 2002. Role of wild Prunus species in the epidemiology of European stone fruit yellows. Plant Pathology, 51: 513-517. https://doi.org/10.1046/j.1365-3059.2002.00732.x

5. Cieślińska M., Morgaś H. 2011. Detection and identification of 'Candidatus Phytoplasma prunorum', 'Candidatus Phytoplasma mali' and 'Candidatus Phytoplasma pyri' in stone fruit trees in Poland. Journal of Phytopathology, 159: $217-222$.

https://doi.org/10.1111/j.1439-0434.2010.01752.x

6. Cieślińska M., Smolarek T. 2015. Molecular diversity of phytoplasmas infecting cherry trees in Poland. Phytopathogenic Mollicutes, 5 (suppl. 1): 31-32. https://doi.org/10.5958/2249-4677.2015.00013.4
7. Čermak V., Lauterer P. 2008. Overwintering of psyllids in South Moravia (Czech Republic) with respect to the vectors of the apple proliferation cluster phytoplasmas. Bulletin of Insectology, 61: 147-148.

8. Deng S., Hiruki C. 1991. Amplification of 16S rRNA genes from culturable and nonculturable mollicutes. Journal of Microbiological Methods, 14: 53-61. https://doi.org/10.1016/0167-7012(91)90007-D

9. Drohojowska J., Głowacka E. 2011. Plant-lice (Hemiptera: Psylloidea) of the Tatra National Park. Polish Journal of Entomology, 80: 265-275. https://doi.org/10.2478/v10200-011-0019-y

10. Fialová R., Navrátil M., Válová P., Lauterer P., Kocourek F., Poncarová-Vorácková Z. 2004. Epidemiology of European stone fruit yellows phytoplasma in the Czech Republic. Acta Horticulturae, 657: 483-487. https://doi.org/10.17660/ActaHortic.2004.657.78

11. Giunchedi L., Poggi Pollini C., Credi R. 1982. Susceptibility of stone fruit trees to the Japanese plum-tree decline causal agent. Acta Horticulturae, 130: 285-90.

12. Goidanich G. 1933. A decay of plum trees. Bollettino Stazione Patologia Vegetale Roma, 13: 160-173 (in Italian).

13. Gundersen D. E., Lee I.-M. 1996. Ultrasensitive detection of phytoplasmas by nested-PCR assays using two universal primers. Phytopathologia Mediterranea, 35: 144-151.

14. Jarausch W., Eyquard J.P., Lansac M., Mohns M., Dosba F. 2000. Susceptibility and tolerance of new French Prunus domestica cultivars to European stone fruit yellows phytoplasma. Journal of Phytopathology, 148: 489-493. https://doi.org/10.1046/j.1439-0434.2000.00535.x

15. Kanturski M., Drohojowska J. 2013. Jumping plant-lice (Hemiptera: Psylloidea) of Garb Tarnogórski. Wiadomości Entomologiczne, 32 (4): 245-254.

16. Klimaszewski S. M. 1963. Polish species of the genus Psylla GEOFF. (Homoptera, Psyllidae). Annales Zoologici, 20: 363-455 (in Polish).

17. Klimaszewski S. M. 1967. Psyllodea. Catalogus Faunae Poloniae, 21 (2): 51 p. (in Polish).

18. Krishnareddy M. 2013. Impact of climate change on insect vectors and vector-borne plant viruses and phytoplasma. Singh H. C. P. et al. (eds). Climate-resilient horticulture: adaptation and mitigation strategies. Springer, India, p. 287-294.

https://doi.org/10.1007/978-81-322-0974-4 23

19. Labonne G., Lichou J. 2004. Data on the life cycle of Cacopsylla pruni, Psyllidae vector of European stone fruit yellows (ESFY) phytoplasma, in France. Acta Horticulturae, 657: 465-470. https://doi.org/10.17660/ActaHortic.2004.657.75

20. Lauterer P. 1999. Results of investigations on Hemiptera in Moravia made by Moravian Museum. (Psylloidea 2). Acta Musei Moraviae, Scientae Biologicae (Brno), 84: 71-151.

21. Lee I.-M., Gundersen-Rindal D. E., Davis R. E., Bartoszyk I. M. 1998. Revised classification scheme of phytoplasmas based on RFLP analyses of 16S rRNA and ribosomal protein gene sequences. International Journal of Systematic Bacteriology, 4: 1153-1169. https://doi.org/10.1099/00207713-48-4-1153

22. Ossiannilsson F. 1992. The Psylloidea (Homoptera) of Fennoscandia and Denmark. Fauna Entomologica Scandinavica, 26: 1-347.

23. Sabaté J., Laviña A., Batlle A. 2015. Incidence and distribution of 'Candidatus Phytoplasma prunorum' and its vector Cacopsylla pruni in Spain: an approach to the epidemiology of the disease and the role of wild Prunus. Plant Pathology, 65: 837-846. https://doi.org/10.1111/ppa.12464 
24. Schneider B., Seemüller E., Smart C. D., Kirkpatrick B. C. 1995. Phylogenetic classification of plant pathogenic myoplasma-like organisms or phytoplasmas. Razin R., Tully J. G. (eds). Molecular diagnostic procedures in mycoplasmology. San Diego, USA, p. 369-380.

25. Smreczyński S. 1954. Materials for true bugs (Hemiptera) of Poland. Fragmenta Faunistica, 7 (1): 1-146 (in Polish). https://doi.org/10.3161/00159301FF1954.7.1.001

26. Steffek R., Follak S., Sauvion N., Labonne G., MacLeod A. 2012. Distribution of 'Candidatus Phytoplasma prunorum' and its vector Cacopsylla pruni in European fruit-growing areas: a review. Bulletin OEPP /EPPO Bulletin, 42: 191-202. https://doi.org/10.1111/epp.2567

27. Tedeschi R., Lauterer P., Brusetti L., Tota F., Alma A. 2009. Composition, abundance and phytoplasma infection in the hawthorn psyllid fauna of Northwestern Italy. European Journal of Plant Pathology, 123: 301-310.

https://doi.org/10.1007/s10658-008-9367-1
28. Thébaud G., Yvon M., Alary R., Sauvion N., Labonne G. 2009. Efficient transmission of 'Candidatus Phytoplasma prunorum' is delayed by eight months due to a long latency in its host-alternating vector. Phytopathology, 99 (3): $265-273$. https://doi.org/10.1094/PHYTO-99-3-0265

29. Tomczyk A.M., Szyga-Pluta K., Majkowska A. 2015. Frost periods and frost-free periods in Poland and neighbouring countries. Open Geosciences, 7 (1): 812-823. https://doi.org/10.1515/geo-2015-0061

30. Yvon M., Labonne G., Thébaud G. 2004. Survival of European stone fruit yellows phytoplasma outside fruit crop production areas: a case study in southeastern France. Acta Horticulture, 657: 477-81. https://doi.org/10.17660/ActaHortic.2004.657.77

31. Weintraub P. G., Beanland L. 2006. Insect vectors of phytoplasmas. Annual Review of Entomology, 51: 91-111. https://doi.org/10.1146/annurev.ento.51.110104.151039

ISSN 1392-3196 / e-ISSN 2335-8947

Zemdirbyste-Agriculture, vol. 105, No. 2 (2018), p. 177-182

DOI $10.13080 / \mathrm{z}-\mathrm{a} .2018 .105 .023$

\title{
Cacopsylla pruni ir jo kaip 'Candidatus Phytoplasma prunorum' pernešėjo svarba Lenkijoje
}

\author{
W. Warabieda, G. Soika, M. Cieślińska \\ Sodininkystès mokslų institutas Skernevicèje, Lenkija
}

\section{Santrauka}

Šokinėjančių augalinių blakučių, ypač Cacopsylla pruni kaip 'Candidatus Phytoplasma prunorum' pernešèjo, rūšinè sudètis buvo tirta kaulavaisių medžiuose 53 vietovèse, daugiausia Centrinèje Lenkijoje. Buvo nustatyta 12 rūšių, priklausančių Psyllidae, Aphalaridae ir Triozidae šeimoms. C. pruni sudare 59,9 \% visų surinktų vabzdžiu aštuoniuose vietovėse slyvų soduose ir dviejose vietovèse vyšnių soduose. Tik trijose vietovèse buvo rasti $C$. pruni vabzdžiai, užsikrètę 'Ca. Phytoplasma prunorum', būtent ant slyvų medžių Mažosios Lenkijos vaivadijoje ir ant mirabelès pomologinès veislių grupès slyvos medžių Mazovijos vaivadijoje. Pastarojoje vietovejje ' $\mathrm{C} a$. Phytoplasma asteris' užsikrètę $C$. pruni vabzdžiai buvo pagauti mirabelès pomologinès veisliu grupès slyvos medžiuose.

Galima daryti išvadą, kad šiuo metu C. pruni nèra didelè grèsmè Lenkijos kaulavaisių sodams, o jo svarba pernešant fitoplazmą, sukeliančią europinę kaulavaisių medžių geltą, nẻra didelè.

Reikšminiai žodžiai: 'Candidatus Phytoplasma asteris', europinė kaulavaisių medžių gelta. 